\title{
Children and Their Rights in Heal The World, Love Will Prevail and Atouna El Toufoule Songs
}

\author{
Nasrum Nasrum ${ }^{1, *}$, Dahlan Dahlan², Asriani Ningsih ${ }^{3}$ \\ ${ }^{1,2,3}$ Alauddin State Islamic University of Makassar \\ *Corresponding author. Email: nasrum.marjuni@ uin-alauddin.ac.id
}

\begin{abstract}
This research discussed the rights of children and the cause of unfulfilled children rights in the songs Heal the world by Michael Jackson, Love will prevail by Maher Zein and Atouna El toefoule by Remi Bandali. This research aims to find out the actual rights of children and the cause of unfulfilled children rights. This research is based on the psychological approach based on Maslow (Hierarchy of Needs) and using the second approach by Marxism theory by Karl Marx. The researchers applied the descriptive qualitative method. The researchers used note-taking as the instrument to find out valid data. The researchers found 25 data that describing children's lives in the three-song lyrics. 5 data in Physiological needs, 10 data in safety needs, 4 data in social needs, 2 data in esteem needs and 4 data in self-Actualization needs. And also, 20 data describe the reasons why children's rights are unfulfilled based on the theory of Marxism by Karl Marx.
\end{abstract}

Keywords: Children rights, Unfulfilled rights, Hierarchy of needs, Marxism, Song, Literary work

\section{INTRODUCTION}

In most depictions of children, they are always portrayed with the image of happiness, heavenly, fun and freedom. Parents have full responsibility for a decent life for their children. All children have the right to get love and protection from everyone around them. Children are God's creatures that must be protected by everyone from various backgrounds. Children are unable to live and determine their destiny without help from those around them such as parents, the government, and other communities.

Children are weak creatures, so they need attention and protection from the society around them. Whatever the reason, children cannot get violence from adults because they will harm their lives later. They must be loved to feel safe and protected. All hopes of children are poured by the parents and adults people around them. So when children feel pressured by societies they will think that their lives are full of oppression. Therefore children have to get proper protection and sufficient affection.

As we know that music is aesthetic literature. Most people choose to create music or sing a song to express their feelings. Almost all people love music, starting from among children, teenagers and even adults. When we are talking about music, of course, we are talking about the song, because both of them have a close relationship. Through the lyrics, the musician can speak their mind, convey what is in their heart and communicate their soul. Song lyrics have two definitions, namely literary works as an outpouring of personal feelings and the composition of a song [1]. It means the lyrics of the song are categorized into poems. A song usually sets the lyrics by the life reflection. Through songs someone can be inspired by good and bad things which can make people cry of sadness, emotion or proud can make people happy and laugh.

Some of the popular songs that make people sad and not even a few people who cry are Heal the World by Michael Jackson, Love Will Prevail by Maher Zein and Atouna El Toufoule by Remi Bandali. These three songs tell how humans and their rights, especially children. Children are human beings who need to be protected. All human beings are born free and equal in dignity and rights. Human rights are premised on the recognition of the equal worth and dignity of every human being regardless of any distinguishing characteristic such as race, colour, sex, language, religion, political, or other opinions, national or social origin, property, birth or another status. This gives rise to the twin fundamental principles of equality and non-discrimination [2]. As we know that children are God's creatures who are weak, because of their weakness they are entitled to protection, love and affection. But these songs show that the children are no longer loved even they have lost their true rights. According to The United Nations 
Convention on the Rights of the Child (1989) defines a child is under the age of 18 and is entitled to the protection and supervision of an adult. At this stage, children are learning through communicating, observing, experiencing, playing and experimenting.

According to Howe and Covell [3], the government only interferes in children's education when their parents are no longer responsible for their children or abuse their responsibilities as parents and the government has full responsibility for children. It means that the parents, the government and even all people must fulfil all children's rights.

The songs of Heal the World by Michael Jackson, Love Will Prevail by Maher Zein and Atouna El Toufoule by Remi Bandali are the songs that represent the feelings of children who cannot get their full rights. These songs are depicted how poor children fight the rigours of their lives. They lost their childhood. Today, some of the children were unlucky children. They lose their true rights. It happens because the authorities no longer give rights to children. This is closely related to the three songs that were the object of the research. The lyrics contained in the three songs are following the reality of children's life. This problem is very interesting to be used as research because it looks at the facts that exist about the deprivation of children's rights often occur in this part of the world. Children cry against the harshness of life that they really can't feel. They do not know love, play and other things related to a happy childhood.

Today many people ignore the rights of children for personal or group interests. Many people do not care about the psychology of children. Children become victims of the actions of adults around them, so through this problem, the researchers are interested in researching children and their rights in these three songs. They describe the feelings of children who have lost their childhood and the songs represent the voices of children who have been deprived of their rights by the authorities. They are sung by famous singers who explain how the rights of children they must receive and fight for the happiness of their childhood.

\section{REFLECTION THEORY (THE HIERARCHY OF NEEDS) BY ABRAHAM MASLOW}

Abraham Maslow is one of the most influential psychologists of the twentieth century. His biggest contributions to psychology were his contributions to humanistic psychology as well as his development of the hierarchy of needs. Maslow's career in psychology greatly predated the modern positive psychology movement, but it might not look the same were it not for him.
He is known as a pioneer of the flow of humanistic psychology. Maslow believes that humans are moved to understand and accept themselves as much as possible. His theory that famous is the theory of the Hierarchy of Needs. His family life and life experiences influenced his psychological ideas. After World War II, Maslow began to question how psychologists had before about the human mind. Although he does not completely deny it, he has his ideas to understand the way of human thought.

Humanist psychologists believe that every person has a strong desire to realize his potential, to reach the level of self-actualization. To prove that humans not only react to situations that occur around them but to achieve something more, Maslow studies someone with a healthy mental state, rather than studying someone with mental health problems. This illustrates that new humans can experience the "peak of experience" when humans are in harmony with themselves and their surroundings. In Maslow's view, humans who actualize themselves can have more peaks of experience than humans who lack actualization of themselves. The symbol of the Hierarchy of needs theory from Abraham Maslow is in the form of a pyramid.

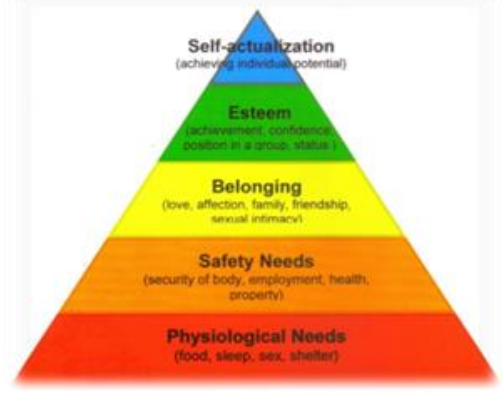

\section{MARXISM}

Marxism is a theory for fighting the proletariat against the bourgeoisie. Marxism theory which is generally seen as the basis of communism's ideology was conceived and developed by Karl Marx and Friedrich Engel is a political manifesto of the communist theory that emphasizes class struggle and economic prosperity. Karl Marx said that a decent human life is the most basic term for human itself [4]. This means that all humans need a decent and comfortable life for survival. Marx noticed that all societies are arranged in such a way time a large group of workers does the Labor of production while a small group of owners reaps the benefits and accumulates wealth.

The beginning of the ideology of Marxism in the 19 th century in which the labour situation in Western Europe was pathetic as industrial progress rapidly developed led to social conditions which were very detrimental to the workers [5]. Based on this problem 
Karl Marx compiled a social theory based on scientific laws. In developing theories about the development of society, he was interested in German philosopher's idea, George Hegel (1170-1831) concerning dialectics. Hegel's philosophy was used by Karl Marx to transform society into radicals. Marxism is a form of Marx's protest against the understanding of capitalism. Capitalism is considered to be superior to the proletariat. Marx argues that this problem arises because of private ownership and control of wealth that is dominated by rich people. Marx argues that to prosper the proletariat, capitalism is replaced with communism. Because this condition continues, based on Marx opinion that the proletariat will rebel and demand justice.

According to Marx, the communists are a society that there is no social class in the structure of society, where man is freed from his personal property, there is no element of exploitation, oppression and coercion. Marx's view of a word that must be fought is emancipation. In the view of Marxism emancipation is used to free people who feel oppressed [11]. The view of Marxism arises when the world is mapped with social classes. The social classes are divided into two, namely the bourgeois class and the proletarian class. In the perspective of Marxism, the class must be changed by the movement of the proletariat and eliminate the class in society. According to Marx, the ideal government is a government-managed by the state not by the bourgeoisie. Because in a good government, there must be class balance, even though there is one governing actor but no one feels oppressed. They only govern the government not exploit the weak. Marxism is also a way of justice for all people, especially in terms of world development. The main aim of the Marxist perspective is to create a classless society so that justice is gained by all groups. Communism is the main agenda of Marxism thinking, the achievement of international communism is one of the aims of Marxism. Marxism rejects the things that are focused on realism and liberalism because according to Marxists, liberal and realist views are too ideologically self-serving, which can be said that liberalism and realism are two views that only think of the social class and themselves.

In the songs of Heal the World, Love Will Prevail and Atouna El Toefoule as the object of this research, we can find the children who are deprived of their rights by the society around them. Here children as the proletariat and the society are the bourgeoisie. The song of love will prevail illustrates that children try to change their social status which is always controlled by society to become independent person. They seemed unwilling to give up on the situation.

\section{CHILDREN'S RIGHTS}

Children's rights are the human rights of children with particular attention to the rights of special protection and care afforded to minors. The African Child Policy Forum (ACPF) in Marjuni [6] as cited in the United Nations Convention on the Rights of the Child defines a child as a human being under the age of 18 years unless, under the law applicable to the child, the majority is attained earlier, so that the children are entitled to protection from all aspects. Damayanti [7] defines a child as any human being below the age of eighteen years unless, under the law applicable to the child, the majority is attained earlier. Children's rights include their right to association with both parents, human identity as well as the basic needs for physical protection, food, universal state-paid education, health care, and criminal laws appropriate for the age and development of the child, equal protection of the child's civil rights, and freedom from discrimination based on the child's race, gender, sexual orientation, gender identity, national origin, religion, disability, colour, ethnicity, or other characteristics.

Children deserve to be given their full rights. His life must be safe and comfortable for the better mental development of children. They must be given adequate housing, adequate food, proper clothing and happy life. Children are our hope, without them, the world feels empty. Children have the right to life protection. They have not been able to fight against people who want to take away their rights. They are weak beings who want love and affection. They only hope through their bright eyes and are unable to say. They are unable to speak and boast about freedom, only tears can signal their hope for decent lives.

\section{METHOD}

This research used the descriptive qualitative method. The researchers analyzed the rights of children depicted in the songs of Heal the World by Michael Jackson, Love Will Prevail by Maher Zein and Atouna El Toufoule by Remi Bandali and also unfulfilled causes of those children's rights. The researchers looked for how the actual rights of children were depicted in the lyrics of the third song as well as the researchers observed why the children rights are not fulfilled. The researchers collected the data through a journal, articles, thesis and books that related to this research. The researchers used note-taking as the instrument of the research. After watching the movie and reading other supporting references, the researchers made some notes that related to the research questions and the objectives of the research. The researchers analyzed the children rights in those three songs by using a psychological approach based on Abraham Maslow (Hierarchy of Needs) and connected with Marxism theory by Karl Marx. 


\section{RESULT AND DISCUSSIONS}

\subsection{The description of children's lives and unfulfilled rights}

Based on Maslow's theory "The hierarchy of Needs", explains that children have five rights that must be fulfilled in their lives, namely physiological rights, safety rights, social rights, Esteem right and selfactualization right. However, in reality, many children do not get full rights. They do not get a decent life, like children in general. Below is a piece of song lyrics about the depiction of children's lives and unfulfilled rights in their lives:

\section{Datum 1}

"If you care enough for the living, make a little space, make a better place". The lyrics of the song illustrate that the proletariat cannot get their full rights. As explained in the theory Hierarchy of Needs by Abraham Maslow, that the basic needs are psychological, namely clothing, food and shelter. However, it is clear from the lyrics "Make a little space, make a better place", that they do not get a decent place to live so that their physiological needs are unfulfilled. Maslow [8] states that Psychological needs are basic needs for life, such as food, drink, shelter and others. So in datum 1 "Make a little space, make a better place" is represented that physiological needs are unfulfilled. Children need a proper place to live so that they feel safe and comfortable.

\section{Datum 2}

"Heal the world" The lyric fragment looks very simple but very meaningful. The children seemed to explain that they had an uncomfortable place to live. They are tormented with their lives, which means physiological needs are completely unfulfilled. Children feel the world is not safe. Psychological needs are basic needs for life, such as food, drink, shelter and others (Maslow, [8]). Children need freedom and do not always have a miserable life.

\section{Datum 3}

"Make it a better place, for you and me and the entire human race". The oppressed wants a decent life for them. Again they focus on housing issues. They need a comfortable place to continue their lives. They need justice. The physiological needs as the main need cannot be fulfilled by the oppressed so that their rights are taken away by the authorities. Again, shelter is a major problem for oppressed people. When this need is not met, it means that basic human needs cannot work properly. Maslow [8] said if these needs are not satisfied the human body cannot function optimally. This illustrates that an adequate place to live is very important for the psychological needs of children.

\section{Datum 4}

"There are people dying". They kill innocent humans, especially children who don't know anything. They are affected by the crimes of the powerful. This shows that their right to feel safe is unfulfilled. According to Maslow [9], one of the needs that must be met is the need for security and safety. For example, emotional security, financial security (e.g. employment, social welfare), law and order, freedom from fear, social stability, property, health and wellbeing. So when a murder occurs, it represents that safety needs are unfulfilled.

\section{Datum 5}

"Love is strong, It only cares for joyful giving, If we try we shall see, in this bliss we cannot feel, fear or dread, We stop existing and start living". In the lyrics of "love is strong", the oppressed people explain to the authorities that if they have a strong love, they will not take away the freedom of innocent children. However, the authorities do not have a strong love for others so that the life that exists is only a fear and anxiety. So that their right to get social/belonging needs are unfulfilled. Maslow [8] states the third level of human needs is social and involves feelings of belongingness. The need for interpersonal relationships motivates behavior. When children do not get love and affection, it represents that social needs are unfulfilled.

\section{Datum 6}

"Then why do we keep strangling life, Wound this earth, crucify it's soul". They explained that their life is very gripping. They are haunted by cruel people. On the lyrics "Wound this earth, crucify it's soul" like representing the earth to comment the rulers that they have destroyed God's beautiful creation, including humans In it. Children want fresh air and a safe earth. Maslow [9]; [8] states that people want to experience order, predictability and control in their lives. These needs can be fulfilled by the family and society (e.g. police, schools, business and medical care). So that, they cannot get safety needs in their lives.

\section{Datum 7}

"We could fly so high, Let our spirits never die". The oppressed children try to strengthen each other in order to get a justice. They strive to gain self-respect as human beings who have no faults. The lyric "We could fly so high" illustrates that they have been oppressed and they have not acted in resistance. Maslow indicated that the need for respect or reputation is most important for children and adolescents and precedes real selfesteem or dignity [9]. The oppressed do not get their rights as humans, namely esteem needs. 


\section{Datum 8}

"Heal the world we live in, save it for our children". In the latest data from the lyrics of the song heal the world my Michael Jackson, it is very clear that all forms of life struggle are proper and safe only for children, because they are God's creatures who have the right to be protected. Children need protection from those around them, but they do not get their rights as children Maslow [8] said People want to experience order, predictability and control in their lives. For example, emotional security, financial security (e.g. employment, social welfare), law and order, freedom from fear, social stability, property, health and wellbeing (e.g. safety against accidents and injury). From the lyric fragment above represents that children lose safety rights.

\section{Datum 9}

"I saw my loved ones die". This lyric of Love Will prevail song by Maher zein shows that people have been killed by the oppressors, even our loved ones. When a murder occurs, it represents that the children are in an insecure phase, the safety needs are unfulfilled. Maslow (1943) states People want control and order in their lives. So, this need for safety and security contributes largely to behaviors at this level. Some of the basic security and safety needs including financial security, health and wellness, Safety against accidents, and injury. They do not get the right to feel safe because they were killed.

\section{Datum 10}

"By God you'll never win, I'll fight for what's right". The oppressed believe that one day they can get justice. They will continue to fight for a peaceful life. The lyric "I'll fight for what's right" illustrates that they must get their rights as humans, namely self actualization. Self-actualization needs are the highest level in Maslow's hierarchy, and refer to the realization of a person's potential, self-fulfillment, seeking personal growth and peak experiences. Maslow [9] describes this level as the desire to accomplish everything that one can, to become the most that one can be. The lyrics of the song represent that self-actualization needs are not fulfilled in children's lives. Therefore, children try to struggle to be able to live a decent life so that they can reach their potential as a human beings.

\section{Datum 11}

"Life's become so cheap". In the lyric it is clear that the oppressors do not care about life, they will kill the people in that land. Maslow [8] states that safety, or security needs, relate to a person's need to feel safe and secure in their life and surroundings. Motivation comes from the need for law, order, and protection from unpredictable and dangerous conditions. So, when a murder occurs it represents that the lives of children are unsafe and dangerous. This is a depiction of life that has not safety right.

\section{Datum 12}

"So many orphans weep". They no longer care for orphans. There is no love and affection in their heart. Children do not get protection like children in general. Children are social creatures that crave interaction with others. This level of the hierarchy outlines the need for friendship, intimacy, family, and love [9]. When children lose love and affection from those around them, it represents that their social needs are unfulfilled, they lose the right to be loved (social needs).

\section{Datum 13}

"They forgot how to smile". Children can only cry because the word happy is very far from their life. They can't feel a beautiful childhood because in real life they are just cruelties. They cannot be protected and loved. According to Maslow [8] humans need to give and receive love to feel like they belong in a group. When deprived of these needs, individuals may experience loneliness or depression. When children forget how to smile, it means they don't get happiness from those around them. They are deprived of love and affection. This represents that children do not get social needs.

\section{Datum 14}

"Just how somebody can, Murder an innocent child". People are sad to see an innocent child die tragically. They were killed by the rulers. Children no longer have their full rights. They lose the right to security in their lives. Based on Maslow [9] point of view, to find stability and security, a person must consider their physical safety. This means seeking protection from the elements, violent conditions, or health threats and sickness. So when children do not get protection and only torture is available, it means safety needs are unfulfilled.

\section{Datum 15}

"God made me free, you can't take that away from me, Freedom is my destiny". They fight for freedom because they believe that God created them with complete freedom. They hope to get justice again because they must be able to show their potential as humans. They did not get that right in their life. According to Maslow's definition of self-actualization, it may be loosely described as the full use and exploitation of talents, capabilities, potentialities, etc [9]. If the children are not able to achieve what they want as in the above lyric, it means children do not get freedom, even though everyone is created by Allah with the same rights, but here self-actualization needs are unfulfilled for children. 


\section{Datum 16}

"I have a dream, and my dream is to see, To see all my people smile, See all of them free and proud" last lyric of Love Will Prevail song illustrates that they want to reach the right to self-actualization, they want to reveal themselves in a beautiful world without any oppression. Maslow [8] states that the need for selfactualization can manifest in different ways, such as obtaining skills, pursuing life dreams and seeking happiness. Children have dreams of being happy, therefore the self-actualization of children are unfulfilled.

\section{Datum 17}

"Give us childhood". The lyric of Athouna El Toufoule song shows simple but very meaningful message. Children need a beautiful childhood like the childhood of children in general. They want freedom, feel safety. Maslow [8] said safety, or security needs, relate to a person's need to feel safe and secure in their life and surroundings. Motivation comes from the need for law, order, and protection from unpredictable and dangerous conditions. But in fact, children get the opposite. They are not given the freedom to play, learn and enjoy the world. Their rights are taken away by the authorities. Therefore, this lyric represents the safety needs of children are unfulfilled.

\section{Datum 18}

"And during the holidays we asked you, why in our place there is no holiday decoration". Children want holiday decorations. They want to enjoy in holiday, but the oppressor do not have strong love and affection for children, they do not care about children's holidays. Maslow [8] states that the social needs in Maslow's hierarchy include such things as love, acceptance, and belonging. At this level, the need for emotional relationships drives human behaviour. But in fact, there is only torture, fear and disappointment. Children lose their right to be loved.

\section{Datum 19}

"My land is burned down". Their place were burned, they were controlled by irresponsible people. There is no longer a safe place for them to feel comfort. Maslow [8] said that physiological needs also include such things as shelter and clothing. These are basic human needs, a proper place to live, but children lose their basic rights.

\section{Datum 20}

"My land's freedom is stolen". Their land has been controlled by irresponsible people, so the children can only stay on the road without thinking about their sense of security and comfort. They lost their true rights. The basic physiological needs are probably fairly apparent these include the things that are vital to our survival.
Some examples of physiological needs include foods, drinks and shelters [8]. Here Children cannot get their physiological needs, namely a place to live.

\section{Datum 21}

"Our sky is dreaming of asking the day, where is the beautiful sun?". They never enjoy the beauty of the sun, the beauty of the change of day and night because they only focus on fighting and saving their lives from the rulers. According to Maslow [8], there are many examples of safety needs in modern society. To find stability and security, a person must consider their physical safety. This means seeking protection from the elements, violent conditions, or health threats and sickness. Here children cannot enjoy their childhood like children in general, because their lives are always miserable. This shows that the safety needs of children are unfulfilled.

\section{Datum 22}

"Give us peace" They just need world peace. They want to live freely without fear. They want to enjoy the world like other people in general. However, it was just a dream for them. Maslow said this security need is more for children because their awareness of selflimitations is still lacking [9]. If the children do not have a safe and peaceful life, it means they do not get the safety right.

\section{Datum 23}

"I am a child with something to say, please listen to me". The rulers did not listen to all their hopes, even though they only hoped that their rights could be fulfilled as children. They needed a happy childhood. But the ruler ignored all of them. Esteem needs are related to a person's need to gain recognition, status, and feel respected [9]. Here the children want their opinions to be respected and heard, but they do not get this right. So the esteem needs of children are unfulfilled.

\section{Datum 24}

"I am a child who wants to play, why don't you let me." Children do not get their right to play because they focus on fighting to save their lives. They cannot play freely because they will be tortured by the oppressors. They hope to reclaim their childhood. According to Maslow [8] safety, or security needs, relate to a person's need to feel safe and secure in their life and surroundings. Motivation comes from the need for law, order, and protection from unpredictable and dangerous conditions. Here children cannot get safety rights in their world, even if they just play with their friends.

\section{Datum 25}

"Give us a chance, please" this lyric of Athouna El Toufoule song ilustrates that children never give up hoping for a little chance to enjoy the beauty of the 
world. The word "please" indicates that they truly hope their rights are not taken away by the oppressor, so that they can play, learn, laugh and be happy. Based on Maslow's point of view, Self-Actualizing people are self-aware concerned with personal growth, less concerned with the opinions of others, and interested in fulfilling their potential [8] Their right to achieve selfactualization is unfulfilled, so they hope they can show their potential.

The twenty-five data that the researchers obtained, illustrate how the lives of children who do not get their rights. They do not get decent lives, protection and affection based on the theory presented by Abraham Maslow "The Hierarchy of Needs" that all children in this world are entitled to five rights, namely Physiological right, safety right, social rights, Esteem right and self-actualization right.

\subsection{The Causes of Unfulfilled Children Rights}

Marxism is a theory for fighting the proletariat against the bourgeoisie. The view of Marxism arises when the world is mapped with social classes. The social classes are divided into two, namely the bourgeois class and the proletarian class. So, the causes of children's rights are not fulfilled because of the existence of the proletariat and the bourgeoisie in life.

\section{Datum 26}

"And if you really try, you'll find there's no need to cry, In this place you'll feel, There's no hurt or sorrow". Here, the proletariat struggles to escape the sorrow and fear of the bourgeoisie. In the lyric "There's no hurt or sorrow" It shows that the bourgeoisie has always hurt the proletariat. The proletariat tries to encourage one another that one day there will be no more torture in their life.

\section{Datum 27}

"If you care enough for the living, Make a little space, make a better place". The bourgeoisie simply does not provide a comfortable place for the bourgeoisie. The bourgeoisie carries out the oppression to the proletariat.

\section{Datum 28}

, "Heal the world". The proletariat hopes that the world will be safe from bourgeoisie evil. They do not want their lives to be dominated by the bourgeoisie.

In datum 4, "Make it a better place, For you and for me and the entire human race". The proletariat wants peace for people whose lives are oppressed. They want to live like people who are free.

\section{Datum 29}

"There are people dying". The bourgeoisie can freely kill the proletariat. There are no rules and no punishments for those who kill the proletariat. No government enforces justice.

Datum 30

"Love is strong, It only cares for joyful giving, If we try we shall see, in this bliss we cannot feel Fear or dread, We stop existing and start living". One of the reasons why the children do not get their true rights is the absence of strong love by the bourgeoisie for the proletariat. The bourgeoisie only takes action which makes the proletariat afraid and disappointed.

\section{Datum 31}

Love's enough for us growing, Make a better world, make a better world. Again, love is an obstacle for children who cannot get the happiness of life. When fellow humans have a strong sense of love, we will live in peace. The lyrics "make a better world, make a better world" repeated twice, which means that the proletariat has a strong hope for a safe and comfortable life.

\section{Datum 32}

"And the world we once believed in, Will shine again in grace, then why do we keep strangling life, wound this earth, crucify it's soul". The proletariat fights to be able to change their social class. The proletariat fights so that they can change their social class. They are saddened to see the beautiful earth destroyed by the wickedness of the bourgeoisie. The bourgeoisie has no compassion for the proletariat.

\section{Datum 33}

"We could fly so high, Let our spirits never die". The proletariat encourages one another to change their social class. They dream of living a decent and comfortable life. They hope that one day the evil of the bourgeoisie will become a strong sense of love and concern.

\section{Datum 34}

"Create a world with no fear, Together we'll cry happy tears, See the nations turn their swords into plowshares, save it for our children". The latest data in the lyrics of the song heal the world by Michael Jackson shows that they hope to be able to live without pressure from irresponsible parties. They hope that the bourgeoisie is able to change their social class and can be protected like children in general. In the lyrics of "save it for our children", it is very clear that children really need a safe and comfortable place, love and love from those around them. But here they are tortured and haunted by fear. The bourgeoisie has no concern for children.

\section{Datum 35}

"I saw my loved ones die, oh, I swear that I won't give in". The bourgeoisie kills the proletariat. The proletariat is a weak creature and can only dream of 
obtaining social justice through the mercy of the bourgeoisie, but this cannot be obtained.

\section{Datum 36}

"By God you'll never win, I'll fight for what's right." The proletariat believes that one day God will answer their prayers. God will open the the hearts of the bourgeoisie so that it will no longer take heartwrenching actions.

\section{Datum 37}

"I will stand my ground". Again the proletariat will not give up in order to achieve social class equality. They continue to fight even though their lives are at stake. Children no longer feel a happy childhood, but they are forced to become adults because of the circumstances they are experiencing.

\section{Datum 38}

"Life's becomes so cheap, so many orphans weep, they forgot how to smile". It is quite clear that the orphaned child was being killed because of the lack of strong love and care from the bourgeoisie. They don't value a person's life, even children have to be victims of their crimes.

\section{Datum 39}

"Just how somebody can murder an innocent child". They will kill innocents because their lust for evil is higher than compassion for children. Children have lost their childhood.

\section{Datum 40}

"You can't take that away from me, Freedom is my destiny". They hope that justice and freedom can be embraced. Here the presence of the government should be able to regulate a safer life as well as punishment for people who are not responsible.

\section{Datum 41}

"Give us childhood ". In the first lyric of Athouna El toefoule song, children ask for their childhood, such as love, affection and protection from those around them, but what they get is torture.

\section{Datum 42}

"O world, my land is burned down, my land's freedom is stolen". The bourgeoisie takes the land of the children, they do not care where the children have to live. This is the cause why the right of children unfulfilled, because the people around them do not foster a caring attitude towards children's life development.

\section{Datum 43}

"Give us peace". The proletariat wants peace. They were tired enough of the wars and crimes of the bourgeoisie. They want a soft heart and embrace each other.

Datum 44

"I am a child who wants to play, why don't you let me". Children want to be free to play like children in general, but the bourgeoisie does not give space to play. Because they can kill, burn the place where the children play. There is no strong love in bourgeoisie heart for the weak.

\section{Datum 45}

"Give us chance, please". In the last lyric of the song "Please" which indicates they are tired in facing an insecure world. They want justice and freedom. They hope that the oppressor hearts can turn into people full of love, compassion and care so that their lives can be more peaceful and comfortable. They can change their social class so that they can be appreciated and loved more like children in general.

The data about the causes of children's unfulfilled rights are similar to the research which was conducted by Liskamalia [10] discusses Child abuse in Danny Boyle's movie (Slumdog Millionaire), there is the physical abuse that occurs in children, such as hitting, blinding, shaking, and kicking. In addition, there is also emotional abuse such as shock and sexual abuse such as prostitution underage. This is caused by the id and ego of the adults in the movie.

Therefore, the researchers also found the reasons why children do not get their true rights based on the theory of Marxism by Karl Marx. Children do not get a proper place to live, protection and affection because there are 3 things according to the theory of Marxism, namely those who act as oppressors, the absence of love for the upper class and the government being less strict about discrimination.

\section{CONCLUSION}

The researchers found 25 data that describing children's lives in the three-song lyrics. There are 5 rights that children cannot get based on the psychological approach by Maslow (Hierarchy of Needs). 5 data in Physiological needs, 10 data in safety needs, 4 data in social needs, 2 data in esteem needs and 4 data in self-Actualization needs. Here children need the right to a proper place, a safe life, strong affection, a sense of respect and able to show their potential to others.

The researcher found 20 data describing the reasons why children's rights are unfulfilled based on the theory of Marxism by Karl Marx. That is:

a. In life some act as the oppressors and the oppressed. Here the children are considered as proletariat and 
the oppressor society is considered as the bourgeoisie.

b. The absence of love, affection, concern and strong protection by the bourgeoisie for the proletariat (the weak children) makes rights unfulfilled.

c. The lack of government regulations on people's lives. The oppressor does not get punished for their actions. Based on Marxism theory the ideal government is a government-managed by the state not by the bourgeoisie. Because in a good government, there must be class balance, even though there is one governing actor but no one feels oppressed.

\section{AUTHORS' CONTRIBUTIONS}

Nasrum and Dahlan carried out the literature review, analyzed the data and wrote the manuscript. Asriani Ningsih participated in the research method. Nasrum and Dahlan drafted the manuscript. All authors read and approved the final manuscript.

\section{ACKNOWLEDGMENTS}

We would like to express gratitude to the Faculty of Letters and Humanities of Alauddin State Islamic University of Makassar for financial and administrative support to our research scheme.

\section{REFERENCES}

[1] Moeliono, Anton. (2003). Kamus Besar Bahasa Indonesia. Jakarta: Depdikbud.

[2] Ensalaco and Linda. (2005). Children's Human Rights. USA: Rowman \& Littlefield Publishers.

[3] Howe and Covell. (2005). Empowering Children: Children's Rights Education as a Pathway to Citizenship. Canada: University of Toronto Press.

[4] Ryan, Michael. (1999). Literary Theory. Blackwell: USA.

[5] Suseno, Franz Magnis. (2005). Pemikiran Karl Marx: Dari Sosialisme Utopis ke Perselisihan Revisionisme. Jakarta: Gramedia Pustaka Utama.

[6] Marjuni, et al. (2018). Children Emotions in Big Hero 6 Movie. English and Literature Journal (2), 65-88.

[7] Damayanti. (1992). Pengertian Anak Tinjauan Kronologis dan Psikologis. Jakarta: Erlangga.

[8] Maslow, A. H. (1954). Motivation and personality. New York: Harper and Row.

[9] Maslow, A. H. (1943). A Theory of Human Motivation. Psychological Review, 50(4), 370-96.

[10] Liskamalia. (2012). Child Abuse in Danny Boyle's Movie Slumdog Millionaire: Psychological
Approach. Adab and Humaties Faculty, Alauddin State Islamic University of Makassar.

[11] Wardhani. (2014). Child Rights in Zimbabwe. A Review of Literature journal, 1(2), 828-837. 